\title{
Penerapan Teknologi Produksi Kopi Herbal Instan Desa Gombengsari, Kecamatan Kalipuro, Kabupaten Banyuwangi
}

\author{
Implementation of Instant Herbal Coffee Production Technology in Gombengsari Village, \\ Kalipuro District, Banyuwangi Regency
}

\author{
Danang SWPJ Widakdo ${ }^{1 *}$, Sefriton ${ }^{1}$, Imam Imroni ${ }^{1}$ \\ ${ }^{1}$ Program Studi Agribisnis, Politeknik Negeri Banyuwangi \\ *danang.sudarso@poliwangi.ac.id
}

\begin{abstract}
ABSTRAK
Desa Gombengsari merupakan salah satu desa di Banyuwangi yang memiliki potensi kopi yang menjanjikan, namun potensi kopi tersebut masih kurang dalam inovasi produk olahan kopi. Salah satu perubahan yang dapat dilakukan adalah pelatihan dan pembuatan Kopi Herbal. Pelatihan dan pembuatan ini bertujuan untuk mengangkat kopi lokal Banyuwangi dan menambah nilai tambah yang tinggi pada produk kopi. Metode yang digunakan adalah penyuluhan dan pelatihan. Penyuluhan bertujuan untuk mengenalkan manfaat dan produk turunan dari kopi herbal, sedangkan praktik bertujuan untuk mendemonstrasikan cara membuat kopi herbal dari proses awal hingga proses pengemasan. Sedangkan tahap terakhir adalah monitoring, yang bertujuan untuk mengevaluasi dan memberikan solusi atas permasalahan yang dihadapi dalam proses pembuatan kopi. Hasil pengabdian kepada masyarakat menunjukkan bahwa produk yang dihasilkan dari kopi herbal instan memiliki ciri khas antara lain rasa dan khasiat yang diberikan dengan harga bahan baku yang terjangkau, penerapan teknologi produksi kopi herbal instan berdampak positif bagi perkembangan kreativitas, sosial dan sektor ekonomi Di sektor lain, pendapatan yang dihasilkan dari pembuatan kopi herbal mampu membayar semua biaya yang dikeluarkan dan mampu menghasilkan keuntungan yang menjanjikan.
\end{abstract}

Kata kunci - Gombengsari, Inovasi, Kopi Herbal Instan

\begin{abstract}
Gombengsari Village is one of the villages in Banyuwangi that has promising coffee potential, but the potential for coffee still lacks in the innovation of processed coffee products. One change that can be done is training and making Herbal Coffee. This training and manufacturing aim to elevate local Banyuwangi coffee and add high added value to coffee products. The method used is counselling and training. Counselling aims to introduce the benefits and derivative products of herbal coffee, while the practice seeks to demonstrate how to make herbal coffee from the initial process to the packaging process. While the final stage is monitoring, which aims to evaluate and provide solutions to problems encountered in the coffee-making process.The results of community service show that the products produced from instant herbal coffee have distinctive features, including the taste and efficacy provided with affordable raw material prices, the application of instant herbal coffee production technology had a positive impact on the development of the creative, social and economic sectors In other sectors, the revenue generated by making herbal coffee was able to pay all costs incurred and be able to produce promising profits.
\end{abstract}

Keywords - Gombengsari, Innovation, Instant Herbal Coffee 


\section{Pendahuluan}

Kabupaten Banyuwangi terletak di ujung paling timur pulau Jawa dan berbatasan langsung dengan kabupaten Situbondo di sebelah utara, Selat Bali di sebelah timur, Samudera Hindia di sebelah selatan, serta kabupaten Jember dan Bondowoso di sebelah barat. Banyuwangi dengan luas wilayah $5.782,50 \mathrm{~km} 2$ memiliki sektor pertanian dan pariwisata yang potensial (BPS kabupaten Banyuwangi, 2018[1] ). Salah satu komoditas pertanian yang cukup diunggulkan adalah komoditas kopi lokal. Desa Gombengsari merupakan salah satu objek wisata di kabupaten Banyuwangi yang memiliki peranan penting dalam memperkenalkan kopi lokal Banyuwangi. Desa ini terletak di dataran tinggi dengan ketinggian 450-500 meter di atas permukaan laut yang menyebabkan daerah ini menjadi daerah penghasil kopi dengan kualitas yang baik. Desa Gombengsari sering disebut sebagai kampung kopi dengan jenis kopi yang terkenal adalah kopi Robusta dan kopi Lanang. Desa ini memiliki perkebunan kopi terluas di Banyuwangi dengan luas lahan sekitar 1.700 hektar.1

Luas lahan yang sangat mumpuni ini masih belum bisa dioptimalkan oleh masyarakat Gombengsari khususnya inovasi hasil kopi, sehingga masyarakat banyak mengalami kendala dan permasalahan ekonomi. Permasalahan yang dihadapi oleh petani kopi di desa tersebut antara lain kurangnya inovasi produk, harga jual kopi yang tidak menentu, dan kurang maksimalnya pengetahuan petani dalam pengolahan kopi. Untuk mengatasi hal tersebut, dibutuhkan inovasi yang dapat mengangkat kopi lokal Banyuwangi, sehingga kopi lokal Banyuwangi tidak hanya digunakan sebagai bahan konsumsi konvensional, melainkan juga memiliki added value yang tinggi. 4

Inovasi produk kopi tersebut diharapkan dapat meningkatkan produktivitas, kemandirian ekonomi, dan brand product daerah. Salah satu inovasi yang akan dikembangkan adalah penerapan teknologi menghasilkan kopi herbal instan dan kemasan produk Kopi herbal merupakan salah satu pengembangan produk minuman kopi yang memberikan manfaat bagi kesehatan karena dicampur dengan rempahrempah dan berbagai bahan herbal pilihan.
Campuran bahan tersebut dapat menghasilkan kopi yang berkualitas baik, seperti rasa, aroma, dan manfaat bagi kesehatan, sehingga aman dan layak untuk dikonsumsi. Salah satu manfaat kopi herbal bagi kesehatan adalah memberikan rasa hangat pada tubuh karena rempah jahe yang terkandung di dalamnya (Saida dkk, 2014 [3] ). Kopi herbal ini akan dikombinasikan dengan susu kambing Etawa yang tentunya akan menambah khasiat dan manfaat dari kopi herbal instan

\section{Target dan Luaran}

Sasaran kegiatan pengabdian kepada masyarakat ini adalah kelompok petani kopi yang ada di desa Gombengsari. Kegiatan pelaksanaan pengabdian pengolahan kopi herbal instan dilakukan dengan praktik langsung bersama petani kopi. Pendekatan teknologi ini diharapkan mampu meningkatkan nilai tambah ekonomi dan nilai-nilai sosial budaya dari proses produksi yang dilakukan petani kopi Desa Gombengsari. Proses penerapan teknologi dilakukan melalui kegiatan pelatihan dan pendampingan. Luaran yang diharapkan dalam kegiatan pengabdian ini adalah terciptanya inovasi kemasan produk kopi herbal instan yang memiliki keunikan khas daerah Gombengsari. Luaran tambahan lainnya adalah terlaksananya pelatihan bagi kelompok petani kopi, sehingga petani dapat menciptakan produk yang memiliki inovasi dan terbentuknya Desa Kopi Mandiri.

\section{Metodologi}

Berdasarkan hasil survey yang telah dilakukan sebelumnya, didapatkan beberapa permasalahan yang oleh mitra. Dari berbagai permasalahan yang ada, maka tim pengusul ide kreatif dan inovatif dengan tujuan memberikan suatu teknologi tepat guna untuk meningkatkan kesejahteraan mitra. Salah satunya pembuatan kopi herbal instan. Metode pelaksanaan dengan penyuluhan, pelatihan, dan monitoring.

1. Memberikan penyuluhan tentang pentingnya penanganan pasca panen kopi untuk diolah menjadi kopi herbal instan salah satu inovasi produk yang memiliki nilai ekonomi. Metode yang digunakan dengan ceramah, diskusi, dan tanya jawab. Fungsinya agar memberikan 
pemahaman kepada petani kopi akan manfaat dari program ini sehingga dapat diterapkan dengan baik.

2. Metode pelatihan dengan mendemonstrasikan cara penggunaan bahan baku utama, memilih bahan, langkah-langkah kerja, dan alat yang digunakan. Di sini petani dapat langsung melakukan, mengerjakan setiap tahapan pembuatan bersama tim, berdiskusi jika kurangnya pemahaman proses tahapan agar petani semakin paham dan bisa menerapkan dari pelatihan yang diberikan. Pelatihan pembuatan pengemasan, pelabelan, pengukuran takaran gram, pemasaran online sehingga produk dari kelompok tani Lego dapat diketahui masyarakat nasional.

3. Metode monitoring untuk mengevaluasi dengan pertemuan kembali pasca pelatihan. Dalam monitoring ini dilakukan diskusi berbagai permasalahan yang ada dan memberikan solusi alternatif masalahnya.

4. Tahapan dalam membuat Kopi Herbal Instan: Biji kopi robusta disangrai kurang lebih 40 menit, kemudian dihaluskan dengan blender, menghasilkan $300 \mathrm{~g}$ bubuk kopi. Selanjutnya memanaskan air sebanyak 5 liter sampai mendidih, memasukkan kopi bubuk rebus kembali sampai mendidih. Hasil perebusan kopi disaring untuk menghasilkan intisari kopi. Rempah-rempah(jahe merah, kunyit, lada hitam dan daun pegagan kering) dicuci bersih, kemudian dihaluskan. Kemudian direbus bahan herbal dengan 2 liter air sampai menyisakan air $1 / 2$, lalu hasil perebusan di saring untuk menghasilkan intisari herbal. Hasil penyaringan kopi dan bahan herbal dimasukkan ke dalam wajan kemudian ditambahkan $1 \mathrm{~kg}$ gula pasir, dipanaskan sambil diaduk sampai menyisakan $1 / 2$ air ditambahkan susu etawa diaduk sampai membentuk Kristal. Selanjutnya didiamkan dan dihaluskan sampai terbentuk kopi herbal instan.

\section{Pembahasan}

\subsection{Result}

Hasil pengabdian Kepada Masyarakat di desa Gombengsari, Kecamatan Kalipuro, Kabupaten Banyuwangi.
1. Tahapan pertama dengan memberikan penyuluhan kepada petani kopi. Tujuan diberikan penyuluhan kepada petani kopi adalah untuk meningkatkan wawasan ilmu pengetahuan tentang pemanfaatan kopi dan produk turunannya. Proses kegiatan ini dihadiri kurang lebih 20 peserta baik ibu-ibu dan bapak-bapak. Salah satu indikator keberhasilan penyuluhan adalah sangat tertarik dengan program yang diberikan karena ada beberapa pertanyaan yang diberikan kepada pemateri seperti manfaat dan kandungan kopi herbal instan serta produk turunannya. Tersaji pada Gambar 1 .

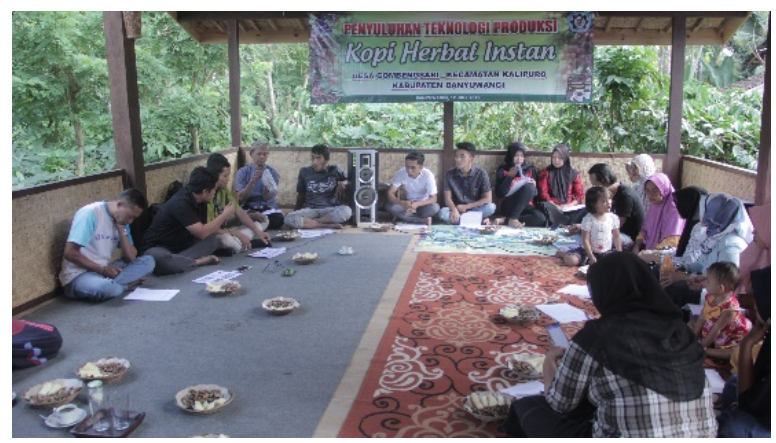

Figure 1. Pemberian materi penyuluhan Teknologi

2. Tahapan kedua dengan memberikan pelatihan kepada petani kopi. Pada tahapan ini menjelaskan proses dalam pembuatan dan bahan baku yang dipergunakan seperti lada hitam, kencur, jahe merah, daun pegagan kering, susu kambing etawa, pala, tersaji pada Gambar 2.

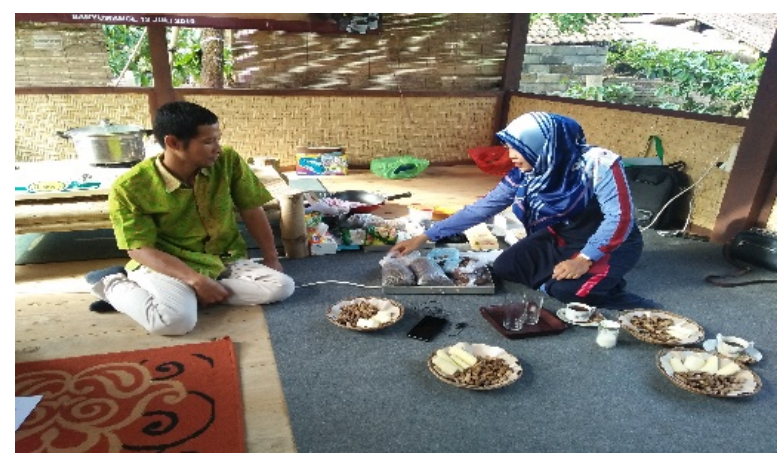

Figure 2. Menjelaskan jenis-jenis bahan baku baku

3. Pada tahapan ketiga proses pembersihan lada hitam, kencur, jahe merah, daun pegagan kering, pada Gambar 3. 


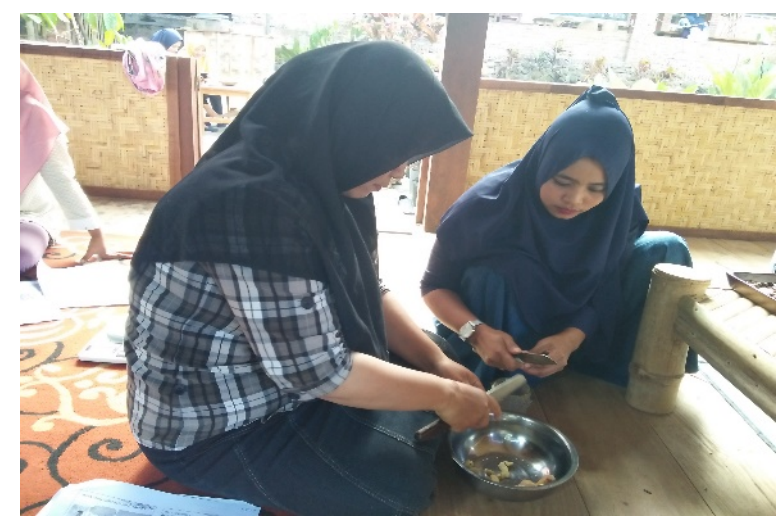

Figure 3. Proses pembersihan bahan baku

4. Pada tahapan ke empat, proses penimbangan bahan baku sesuai dengan standar dalam pembuatan kopi herbal, tersaji pada Gambar 4.

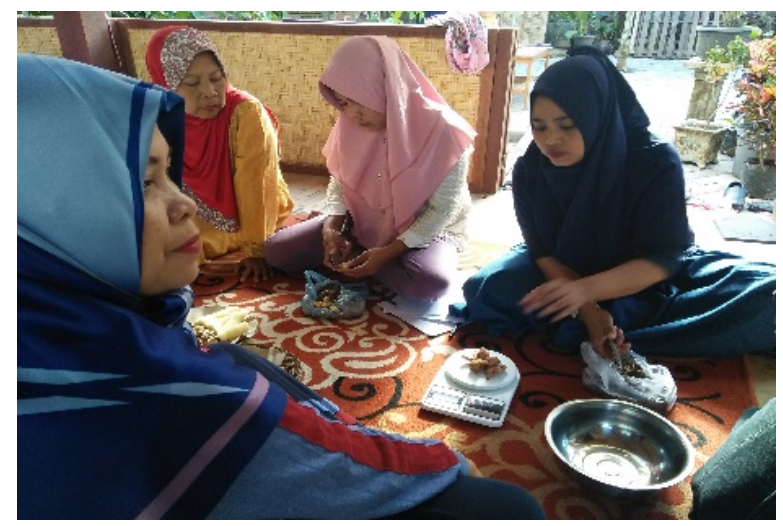

Figure 4. Proses penimbangan bahan baku

5. Pada tahapan ke lima, proses penghalusan bahan lada hitam, pala dan kopi. Tersaji pada Gambar 5.

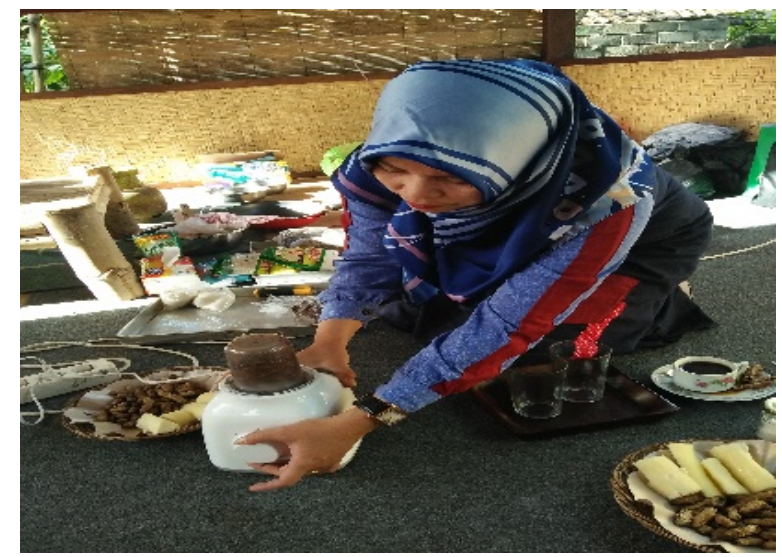

Figure 5. Proses penghalusan bahan baku

6. Pada tahapan keenam proses pemberian air hangat pada daun pegagang, pada Gambar 6.

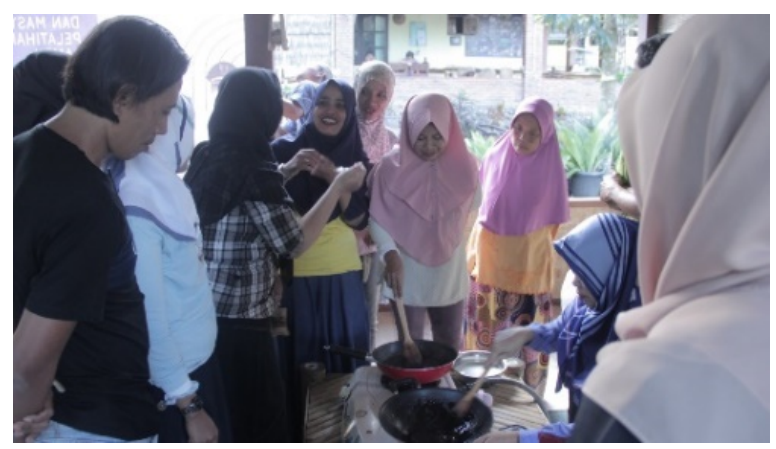

Figure 6. Proses ini pemberian air hangat pada daun pegagang

7. Pada tahapan ketujuh proses ekstrak daun pegagang dengan tujuan untuk menghasilkan sari daun pegangan, pada Gambar 7.

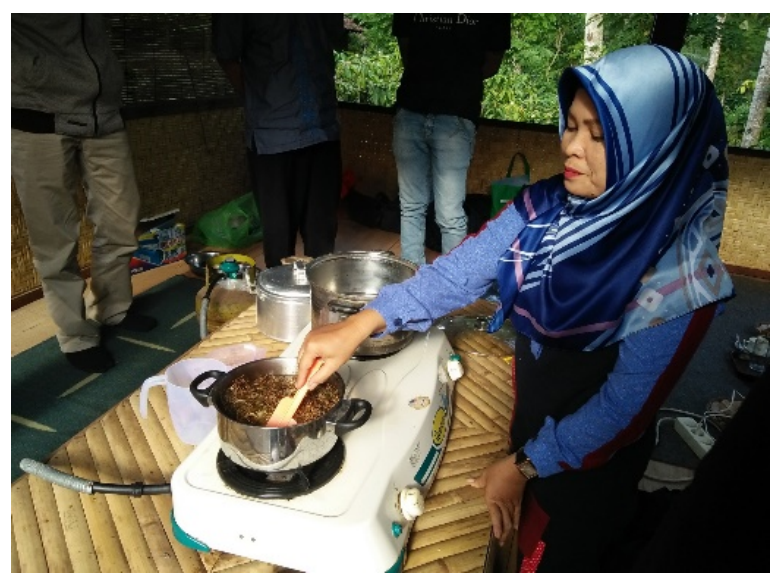

Figure 7. Proses ekstrak daun pegagang

8. Pada tahapan kedelapan proses penyaringan daun pegagang dan pencampuran ekstrak kopi dan rempah-rempah yang dicampurkan pada Gambar 8.

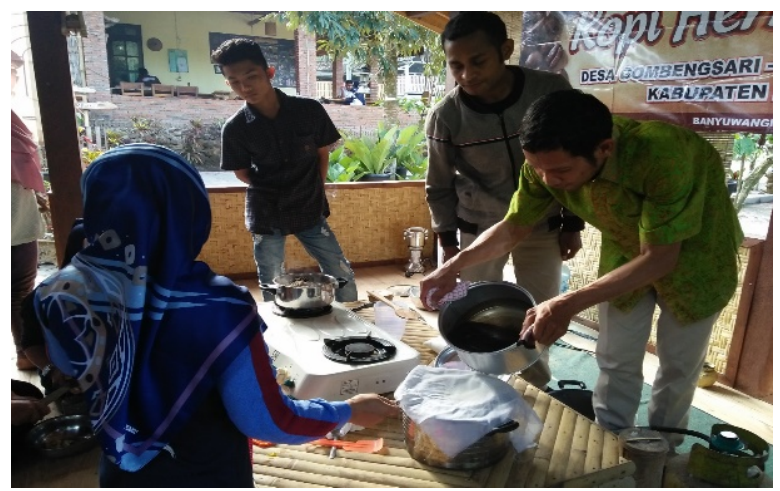

Figure 8. Proses penyaringan dan pencampuran bahan baku

9. Pada tahapan kesembilan proses pengadukan kopi sampai mengkristal pada Gambar 9. 


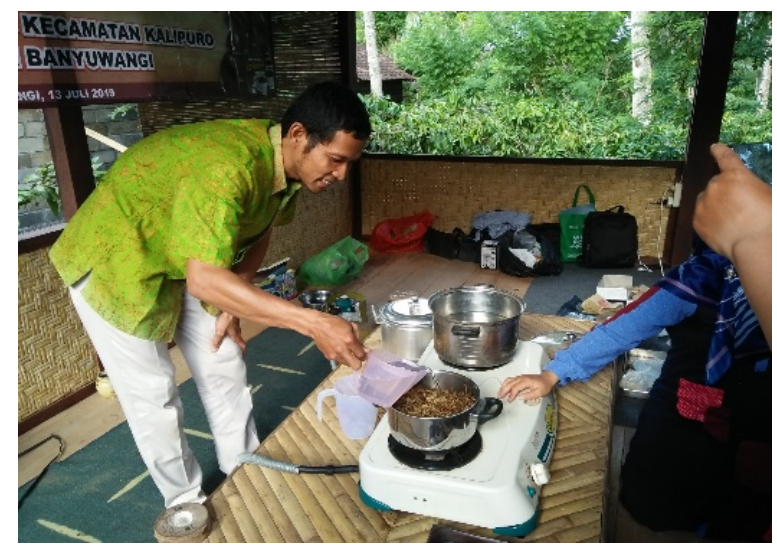

Figure 9. Proses pengadukan kopi herbal

10. Pada tahapan kesepuluh dimana proses pengadukan sampai membentuk kopi berwarna hitam ada putihnya menandakan kopi sudah jadi pada Gambar 10.

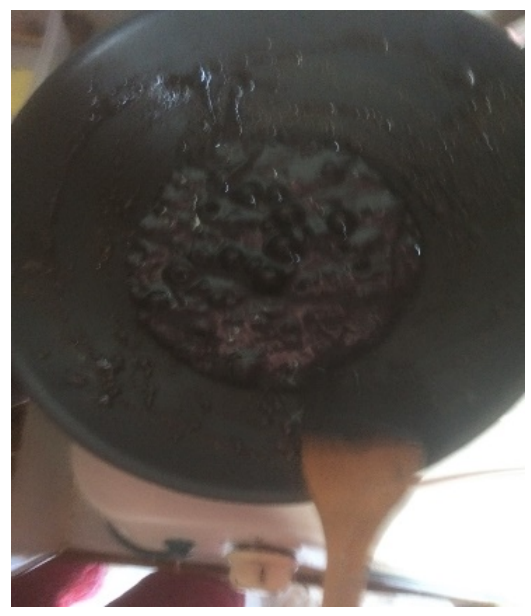

Figure 10. Proses pengadukan kopi

11. Pada tahapan kesebelas, mahasiswa terlibat langsung dalam proses pengadukan kopi sampai mengkristal pada Gambar 11.

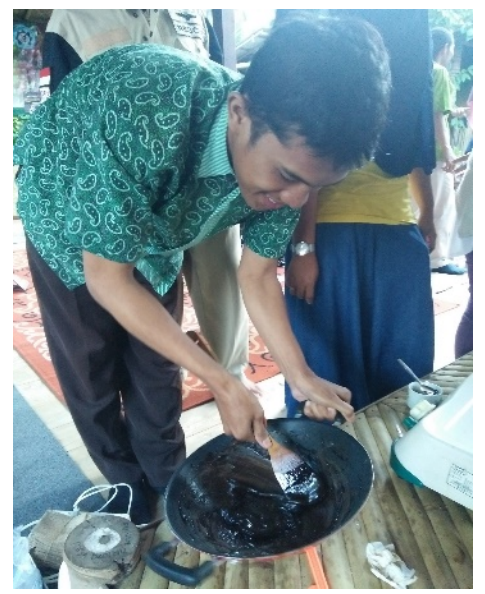

Figure 11. Proses pengadukan sampai mengeras
12. Pada tahapan dua belas, kopi yang jadi. Selanjutnya dihaluskan menjadi serbuk halus untuk dikemas menjadi kopi herbal instan pada Gambar 12.

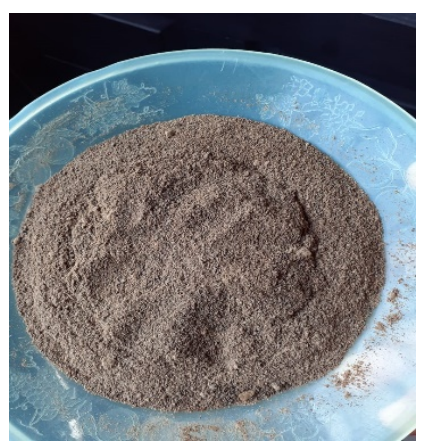

Figure 12. Kopi bubuk Herbal

13. Pada tahapan tiga belas, kopi yang halus selanjutnya dikemas menggunakan kemasan dengan ukuran $50 \mathrm{~g}$, dan $150 \mathrm{~g}$ menjadi kopi herbal instan pada Gambar 13.

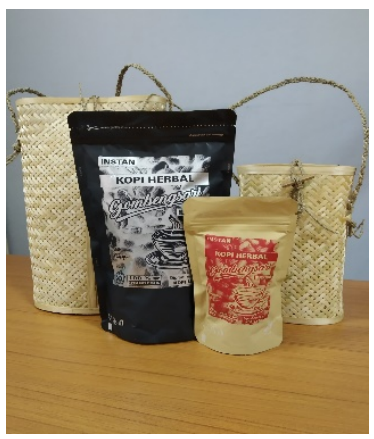

Figure 13. Kopi herbal instan

14. Pada tahapan empat belas, penyerahan bahan dan alat ke petani kopi pada Gambar 14.

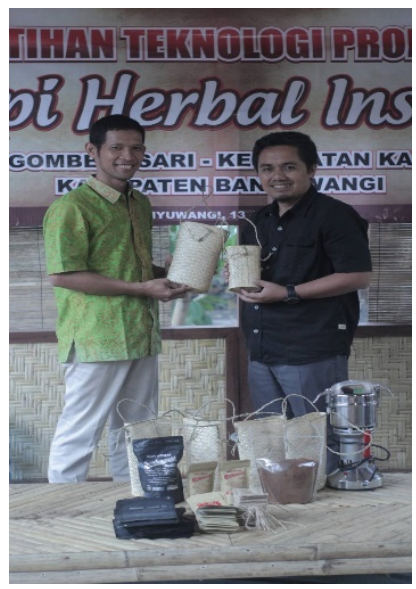

Figure 14. Penyerahan bahan dan alat 


\subsection{Discussion}

Hasil kegiatan pelaksanaan penyuluhan dan pelatihan Teknologi Produksi Kopi Herbal Instan di Desa Gombengsari, Kecamatan Kalipuro yang dilaksanakan bulan Juli hingga bulan November 2019. Metode pelaksanaan kegiatan ini yaitu Penyuluhan dan Pelatihan. Metode penyuluhan memberikan penjelasan tentang potensi kopi herbal, bahan dan kandungan yang dipergunakan, manfaat, pengemasan dan pemasarannya. Sedangkan metode pelatihan ini menjelaskan tahapantahapan pembuatan kopi herbal instan dengan melibatkan seluruh peserta dalam kegiatan ini. Selanjutnya pendampingan dan monitoring untuk mengetahui penerapan kegiatan usaha yang dilaksanakan oleh mitra dan kendalanya untuk mendapatkan solusi yang terbaik.

Sasaran strategis kegiatan pengabdian kepada masyarakat ini melibatkan petani kopi, tokoh masyarakat dan pengusaha kopi. Berdasarkan peserta yang terlibat kegiatan pengabdian kepada masyarakat berdasarkan tingkat pendidikan SMA sebesar 54\%, sedangkan tingkat pendidikan SD sebesar 38\%, dan tingkat pendidikan Perguruan Tinggi (S1) sebesar 8\% disajikan pada Gambar 15.

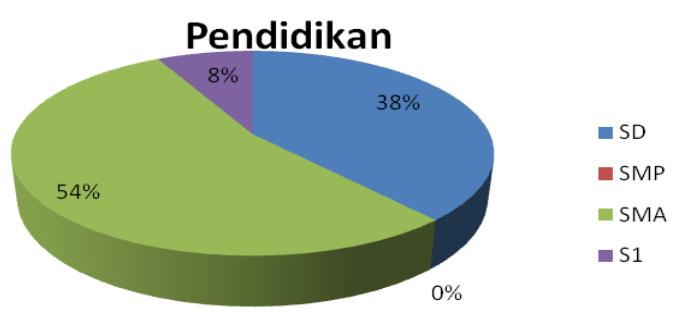

Figure 15. Pendidikan peserta Pengabdian kepada Masyarakat

Peserta yang terlibat dalam kegiatan pengabdian kepada masyarakat, secara keseluruhan bekerja sebagai ibu rumah tangga dengan nilai sebesar 50\%, sedangkan wiraswasta sebesar 38\%, dan admin kontraktor dan swasta sebesar 12\% disajikan pada Gambar 16 .

Evaluasi pelaksanaan kegiatan pengabdian kepada masyarakat dengan menggunakan metode pre test dan post test pada materi yang diberikan. Kategori tingkat pemahaman peserta berdasarkan materi yang disampaikan sebesar $64 \%$ dengan penilaian baik, untuk produk turunan kopi sebesar 73\% dengan penilaian baik, sedangkan manfaat kopi herbal sebesar 45\% dengan asumsi sangat baik, sedangkan untuk usaha sebesar $45 \%$ dengan penilaian cukup disajikan pada Gambar 17.

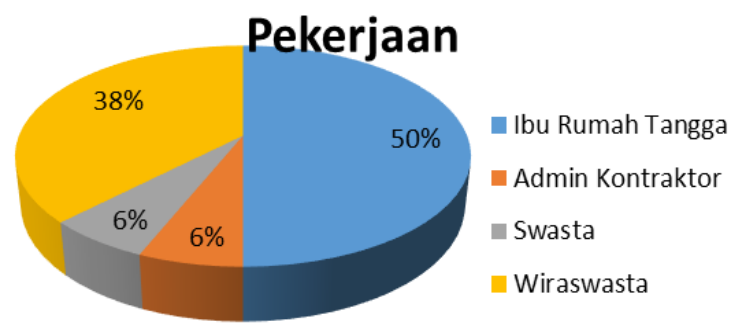

Figure 16. Pekerjaan peserta Pengabdian kepada Masyarakat

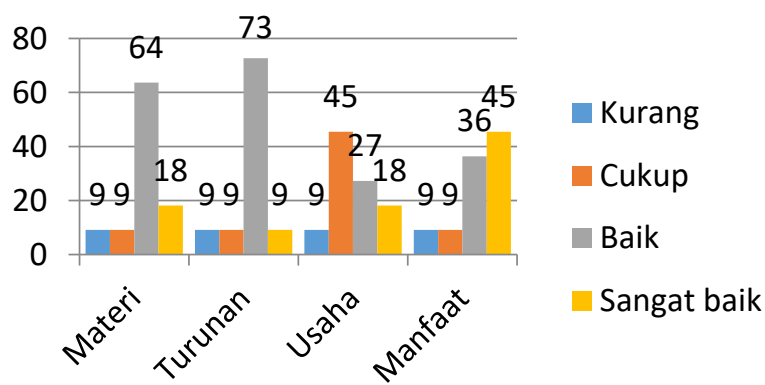

Figure 17. Pemahaman tentang materi

Pada penyuluhan Pengukuran tingkat pemahaman peserta terkait kandungan gizi dan manfaat atau khasiat kopi herbal instan dengan nilai sebesar $82,35 \%$ hingga $88,89 \%$, sedangkan ketidaktahuan peserta untuk manfaat kopi herbal dari $11,11 \%$ hingga $17,65 \%$ tersaji pada Gambar 18.

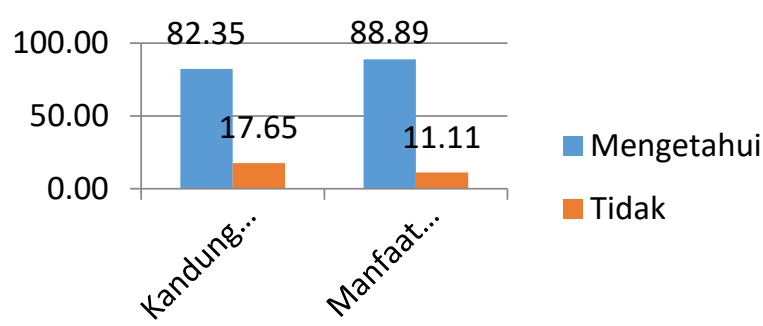

Figure 18. Kandungan gizi dan manfaatnya

Penyampaian materi tentang produk turunan kopi, untuk mengukur tingkat pemahaman peserta tentang kopi menjadi masker sebesar $70,59 \%$, sedangkan $29,41 \%$ tidak mengetahui. Kopi dijadikan sabun tingkat 
pemahaman sebesar $86,67 \%$, sedangkan $13,33 \%$ tidak mengetahui. Kopi dijadikan selai tingkat pemahaman sebesar 86,67\%, sedangkan 13,33\% tidak tahu. Kopi dijadikan parfum tingkat pemahaman sebesar $85,71 \%$, sedangkan $14,29 \%$ tidak mengetahui. Selanjutnya kopi dijadikan permen tingkat pemahaman sebesar $75,00 \%$ dan $25 \%$ tidak mengetahui. Sedangkan kopi dijadikan pudding tingkat pemahaman sebesar $91,67 \%$, sedangkan tidak memahami sebesar $8,33 \%$ tersaji pada gambar 19 .

Hasil analisis usaha tani Kopi Herbal Instan adalah seluruh komponen biaya yang dikeluarkan dalam satu kali produksi. Biaya total yang dikeluarkan terdiri variabel dan biaya tetap. Biaya variabel meliputi gula pasir, kopi bubuk, pegagan kering, jahe merah segar, kencur segar, biji pala, lada hitam, gas LPG, sewa alat, kemasan eco pack $(100 \mathrm{~g})$, biaya lain-lain (air, listrik), kemasan bambu $50 \mathrm{~g}$, dan kemasan bambu 150 gram. Biaya tetap meliputi tenaga kerja, penyusutan alat pada Tabel 1 .

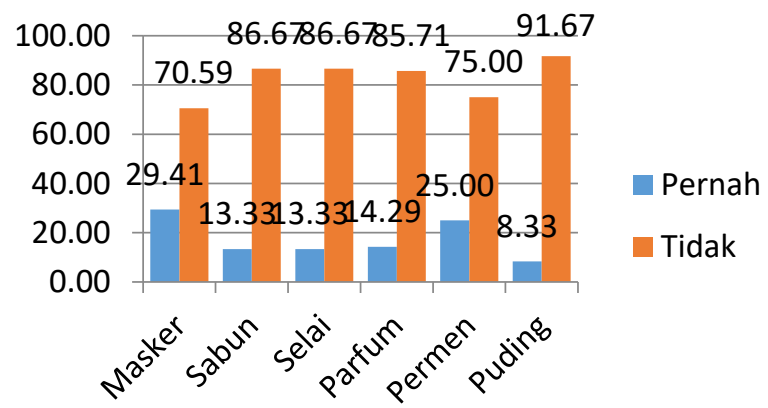

Figure 19. Produk turunan kopi

Table 1. Analisis Usaha

\begin{tabular}{|c|c|c|c|c|}
\hline Bahan & Jumlah Bahan & Satuan & Harga Bahan per kg & Harga Total \\
\hline \multicolumn{5}{|l|}{ Penerimaan } \\
\hline \multicolumn{5}{|l|}{ Produksi yang dijual } \\
\hline Kemasan $50 \mathrm{~g}$ & 23 & pack & 45.000 & 1.035 .000 \\
\hline Kemasan $150 \mathrm{~g}$ & 8 & pack & 135.000 & 1.080 .000 \\
\hline \multicolumn{4}{|l|}{ Total penerimaan } & 2.115 .000 \\
\hline \multicolumn{5}{|l|}{ Biaya Tetap } \\
\hline Tenaga kerja & 2 & $\mathrm{OH}$ & 40.000 & 80.000 \\
\hline Penyusutan Alat & 12 & alat & 381.13 & 4.573 .61 \\
\hline \multicolumn{4}{|l|}{ Total Biaya Tetap } & 84.573 .61 \\
\hline \multicolumn{5}{|l|}{ Biaya Variabel } \\
\hline Gula Pasir & 2 & $\mathrm{~kg}$ & 15.000 & 30.000 \\
\hline Kopi bubuk & 0.6 & $\mathrm{~kg}$ & 130.000 & 78.000 \\
\hline Pegagan kering & 0.3 & $\mathrm{~kg}$ & 250.000 & 75.000 \\
\hline Jahe merah segar & 0.3 & $\mathrm{~kg}$ & 40.000 & 12.000 \\
\hline Kencur segar & 0.2 & $\mathrm{~kg}$ & 40.000 & 8.000 \\
\hline Biji pala & 0.1 & $\mathrm{~kg}$ & 100.000 & 10.000 \\
\hline Lada hitam & 0.06 & $\mathrm{~kg}$ & 200.000 & 12.000 \\
\hline Gas LPG & 4 & jam & 5.000 & 40.000 \\
\hline Sewa alat /Susut Alat & 2 & hari & 5.000 & 10.000 \\
\hline Kemasan eco pack (100g) & 24 & lbr & 1.200 & 28.800 \\
\hline Biaya lain-lain & 2 & & 7.500 & 15.000 \\
\hline Kemasan Bambu 50 gram & 23 & pack & 20.000 & 460.000 \\
\hline Kemasan Bambu 150 gram & 8 & pack & 25.000 & 200.000 \\
\hline \multicolumn{3}{|l|}{ Total Biaya Variabel } & \multicolumn{2}{|l|}{978.800} \\
\hline \multicolumn{3}{|l|}{ Total Biaya } & \multicolumn{2}{|l|}{1.063 .374} \\
\hline \multicolumn{3}{|l|}{ Keuntungan } & \multicolumn{2}{|l|}{1.051 .626} \\
\hline
\end{tabular}

Analisis pendapatan Keuntungan usaha Kopi Herbal Instan pada Tabel 1 menunjukkan bahwa dalam satu kali produksi menghasilkan keuntungan sebesar Rp 1.051.626. Pendapatan usaha kopi herbal instan yang diperoleh telah cukup untuk membayar seluruh biaya pembelian sarana produksi yang diperhitungkan dan menghasilkan keuntungan signifikan. 


\section{Kesimpulan}

a. Produk yang dihasilkan dari kopi herbal instan memiliki ciri khas dengan bahan baku cukup terjangkau dengan nilai tambah dari kopi biasa.

b. Penerapan teknologi produksi kopi herbal instan berdampak positif dalam sektor ekonomi kreatif, sosial, dan berkontribusi terhadap sektor lainnya.

c. Hasil analisis usaha menunjukkan potensi usaha kopi herbal instan sangat menjanjikan.

\section{Ucapan Terima Kasih}

Saya berterima kasih kepada Direktorat Jenderal Penguatan Riset dan Pengembangan Kementerian Riset, Teknologi, dan Pendidikan Tinggi untuk mendanai Hibah Pengabdian Kepada Masyarakat pada tahun 2019, dan Politeknik Negeri Banyuwangi. Tidak lupa semua yang terlibat dalam kesuksesan Pengabdian Kepada Masyarakat.

\section{Daftar Pustaka}

[1] Badan Pusat Statistik Kabupaten Banyuwangi. 2018. https://banyuwangikab.bps.go.id/

[2] Dalimartha, S. 2006. Atlas Tumbuhan Obat Indonesia. Jilid 2 Cetakan ke-IV. Trubus Agriwidya. Jakarta.

[3] Rosmalia Saida, Hilda., Nurhayati, Bambang Herry Purnomo dan Eka Ruriani. 2014. Analisis Kelayakan Finansial Produk Kopi Herbal Instan Terproduksi Oleh UD. Sari Alam. Jurnal Agroteknologi. Vol. 08, No. 02 .

[4] Purwanto YA, Murtilaksono K, Yusuf SM. 2015. Model Pemberdayaan Masyarakat Melalui Pengolahan Kopi di Desa Mandiri Energi. Jurnal Agrokreatif. Vol. 1(1):28-24. ISSN: 2460-8572. 